\title{
Cage-Interview Nr. 1 / No. 1 \\ Huddersfield Contemporary Music Festival, 1989 \\ 9:30 a.m. 25/11/89 in Cage's Temporary Flat, 53 New North Road, Huddersfield Steve Sweeney-Turner im Gespräch mit John Cage
}

\section{[Online-Einrichtung von Clemens Gresser, Wolfgang Krebs]}

SST: I think that in a lot of ways we have no discourse to engage with indeterminate music. For instance, I was reading dictionaries, looking up all the words, whether it was figured bass, or indeterminacy itself...

JC: Mmm. Ha ha ha ha. You mean there are no words for it?

There are no words for it! They didn't even fill up one side of A4 and they were all basically defined in terms of lack, absence, and so forth. It strikes me that there is no actual discourse extant to deal with it, a discourse which is based in indeterminist ethics, rather than determinist ethics.

I think it's in the field of anarchy. You can do it there... Start there... Read the life of Emma Goldman. ${ }^{1}$ Two volumes. Ha ha ha. Living my Life. ${ }^{2}$ Ha ha ha... The old ideas, the determinist ideas, have to do with the nineteenth century, and if you read the book that the Huddersfield Festival put out ${ }^{3}$, it places

1 Emma Goldman (1869-1940), amerikanische Anarchistin und Feministin litauischer Abstammung. Weitere Informationen unter:

http://sunsite.berkeley.edu/Goldman/Guide/.

2 Ihre Autobiographie Living My Life, 2 Bd., New York (Alfred A. Knopf) 1931, umfaßt über 1000 Seiten. Nachdruck bei Garden City, N.Y. (Garden City Publishing Company) 1934. Momentan verfügbare deutsche Fassung: Gelebtes Leben, Berlin (K. Kramer) 1988.

3 Gemeint ist das Programm für das Huddersfield Contemporary Music Festival 1989. 
Boulez, even, in that situation with respect to Beethoven - continuing the main stream. But, uh, there's another way of looking at things, which sees that the main stream has now gone into delta. And beyond that into ocean...

...diffusion...

...yes, and there's a multiplicity of possibilities rather than just one principle one. When I was young there were two ways of going - one was Schönberg, and the other was Stravinsky. ${ }^{4}$ But now you can go in any direction at all, even your own direction.

Yeah. Although, in the Festival blurb you're presented as Cage and Boulez: "Divergent Leaders of The New", which seems to suggest that old situation again.

Yeah, it's sort of silly, because it's an idea of Yes or No, and we already agreed that it's more like ocean - many possibilities... life is quite, em... complicated. But when you say "critical", a "critical basis", you're speaking of a decision about values, I suppose; but the values exist not outside of us, but inside of us... and particularly in indeterminate work. I don't think, uh... maybe the desire is unnecessary. So that we don't need any basis... we have the basis in us already. It's built-in. Ha ha. You can't prove it to anybody, either.

Sure, sure. But as far as the things "outside" are organised, it seems everything is based in determinist ethics in terms of the generation of discourse.

$4 \quad$ Siehe auch Jeff Goldberg, John Cage Interviewed, in: Transatlantic Review, Vl. 55/56, 1976, S. 103.

5 Siehe Fußnote 3. 
Not the things that we need. Forgive me, but you said we need a basis for indeterminate criticism, hm? Criticism of indeterminate music? I don't think we need criticism in the first place.

Well, rather than "criticism", as implying condemnation, or something, I'm talking about a language, a discourse...

That's what I mean. You can get to language by going to the beginning of the words about indeterminacy: I've written a good deal about it, ${ }^{6}$ so has Christian Wolff, ${ }^{7}$ and I think you'll get it in the American Grove's ${ }^{8}$... But you see, the desire to have a language in order to have a criticism is perhaps not necessary; it's related to laws and theory, and so forth... and indeterminacy is precisely not related to those things.

Well, in that to establish indeterminacy you have to step back from the determinist lexis, and locus, that music has adopted... that is necessarily a theoretical stance, surely? Do you not think? That if we think other than the determinist position, then it's necessarily a decision to oppose that stance...

6 John Cage, Silence, London (Marion Boyars) 1968, S. 260-273; John Cage, I-VI, Cambridge, Massachusetts (Harvard University Press) 1990, S. 431-433.

7 Siehe Christian Wolff, Precise Actions under Variously Indeterminate Conditions. On Form / Genaueste Handlungen unter den freiesten Bedingungen. Über Form, in: Christian Wolff, Cues/Hinweise. Writings and Conversations/Schriften und Gespräche, hrsg. von G. Grönemeyer und R. Oehlschlägel, Köln (musiktexte verlag) 1988. Christian Wolff (geb. 1934 in Nizza/Frankreich) begann mit ersten Kompositionsversuchen Ende der 1940er Jahre. 1950 lernte Wolff John Cage kennen und wurde Mitglied der sogenannten 'New York School', zu der auch Morton Feldman und Earle Brown gehörten. Seit 1971 lehrt Wolff am Dartmouth College in Hannover/New Hampshire (Komposition und klassische Philologie). In den 1960er Jahren lernte er Cornelius Cardew kennen. Wolff ist für Musik bekannt, die sich mit der Interaktion zwischen den Ausführenden auseinandersetzt. Weitere Informationen etwa in Komponisten der Gegenwart, herausgegeben von Hanns-Werner Heister und Walter-Wolfgang Sparrer, München. (Verlag edition text und kritik), fortlaufend aktualisiertes Loseblatt-Lexikon.

8 The new Grove dictionary of American music, hrsg. von H. Wiley Hitchcock und Stanley Sadie, London (Macmillan) 1986, 4 Bd. 
You're taking a different point of view, yes? Em, changing your mind from the determinist position to a non-determinist position... The determinist position has been that each performance is an approach to an ideal. Okay? The indeterminist position is that each performance is necessarily what it is, and you'd better listen while it's going on, otherwise you'll miss it. Mm? And I prefer that point of view; I think it's more appropriate to twentieth century living than the other one. The other one has a kind of an assumption of progress towards a non-existent, em... or toward an imaginary goal, rather than the now-moment. The indeterminist position is all connected with seeing how things are at the moment when you're experiencing them.

Yeah... So how do you see your notion of indeterminacy differing from others subscribed to, particularly in Europe? For instance, people like Stockhausen, Cardew ${ }^{9}$, you know?

How we're different? I haven't studied that... I don't think Karlheinz studies what I do... and Cornelius is dead! Ha ha ha.

Ha ha ha ha!

So I really don't know what's happening...

9 Cornelius Cardew (1936-1981), engl. Komponist und Musiker, der von 1958 bis 1960 ein Assistent von Karlheinz Stockhausen war; später lehnte er aber besonders Stockhausen sowie die modernistisch-elitäre Tendenz der zeitgenössischen Musik ab und gründete das Scratch Orchestra. Dieses Ensemble bestand aus Laien und professionellen Musikern und Komponisten und protestierte mit seinen oft unkonventionellen Aufführungen gegen das musikkulturelle, aber auch das politische Establishment. 1979 gehörte Cardew zu den Gründungsmitgliedern der Revolutionary Communist Party of Britain, die marxistisch-leninistisch ausgerichtet war. Am 13. Dezember 1981 wurde er mutwillig in London von einem Auto überfahren. 
However, it's often suggested that Stockhausen was influenced by your work, by your visit to Darmstadt in... '57 or '58, was it ${ }^{10}$ ?

Right. No, I think people know perfectly well what interests them. And at one time Karlheinz and I would talk and exchange ideas. You know the story about the talk about singing?

No, I don't think I do.

Well, he was writing a song for Cathy Berberian, who I later also wrote for ${ }^{11}$, and he said, "if you were writing for a singer, would you write music, or would you write for the singer?" And I said, "I would write for the singer", and he said, "well that's the difference between us, because I would write music." So then he wrote this song for Cathy, and he asked her to whistle. And she can't whistle. So that's the difference between us. Hmhmhmhm!

Ha ha ha. So what would you say is the difference between you and Cardew?

I don't know, in those terms. He, um, wrote an article against what I was doing $^{12}$, em... and I never objected to it... or never wrote in opposition to it. Later, he saw me in Berlin, and he said, "I may have made a mistake in writing that article about you". And I said nothing.

10 Cage war 1958 und 1990 bei den Darmstädter Ferienkursen zu Gast; siehe HeinzKlaus Metzger, Fragment zum Thema "Komet" (Erinnerungen an Cage), in: Von Kranichstein zur Gegenwart. 50 Jahre Darmstädter Ferienkurse (1946-1996), hrsg. von Rudolf Stephan u.a. im Auftrag des Internationalen Musikinstituts Darmstadt, Stuttgart: DACO Verlag 1996, S. 250-251 bzw. Rita Latocha, "Jeder Tag ist ein schöner Tag". Erinnerungen an John Cage 1990, ebd., S. 253-256.

11 Beispielsweise in der Komposition Song Books (1970), 3-92 Solos für eine oder mehrere Stimmen.

12 Cornelius Cardew, John Cage: ghost or monster?, in: Listener, 87/1972 (4 May), S. 597-598. 
Uhu... Although I've read you polemicising against Cardew...

What was that?

It's the interview that's published as a wee booklet, uh, Conversation Without Feldman - with Geoffrey Barnard ${ }^{13}$, and it seems that the beginning and the end, to put it that way, is about Cardew, and what you saw as the failures, in a sense, or inconsistencies, or whatever.

I haven't read that recently... We had quite a lot of difficulty toward the end: he was employed, for instance, once, to play a piano part in my piece called $H P S C H D^{14}$ and he made a point of not doing his work well, and that kind of situation made difficulty [sic] for us.

That attitude annoys you...

It seems to me unprofessional, if you accept payment to do something and then don't do it, that is unprofessional. What I think it... it actually bound up with my practical side; I found that what Cornelius was doing, didn't help the Revolution as much as he would have liked it to help, hm? And it also didn't help music, hm? Because his music became less a discovery and more and more the revival of nineteenth century practises.

13 Conversation without Feldman: a talk between John Cage \& Geoffrey Barnard, Darlinghurst, N.S.W. (Black Ram Books) 1980.

14 HPSCHD (1967-1969) für sieben Cembali und Tonbänder in Kollaboration mit Lejaren Hiller (Komponist von Computermusik). Der Titel leitet sich ab von dem englischen Wort für Cembalo (harpsichord): Da der Name, der für diese Komposition verwendeten Rechenprozedur nur sechsstellig sein durfte, ergab sich die Abkürzung "HPSCHD". Hiller half Cage bei dieser Komposition, in dem er ein Programm zur Erzeugung von computergenerierten musikalischen Material erzeugte. 
But also, in a sense, an analysis of that kind of English notion; an analysis based on political grounds.

I had liked and followed a great deal of Cornelius' work, and he was a very, uh... I really haven't studied my thoughts about that... or come to any... I don't feel as though I have a... a point of view... but if I have, I'm afraid it is a little bit against... as you say, in the Geoffrey Barnard...

Uhu... How do you feel about the book Stockhausen Serves Imperialism? ${ }^{15}$ You know that, yeah?

That's Cornelius, isn't it? I didn't like it.

On what grounds?

Well, more or less the grounds that, em... it was an attack on the part of Cornelius against people who were doing their work. And instead of doing his own work, he got involved in attacking other people who were working. Hm? So that he didn't do himself any good, or them any good. I think... it was negative action - that's what I really object to. I think people should act affirmatively and do what they believe. I think Cornelius failed to do that when he attacked other people, including me. And he even said to me that he thought he may have made a mistake, but he didn't admit that it was a mistake to attack Stockhausen.

Did you agree with anything that he said about Stockhausen, or did you just write it off on that basis?

15 Cornelius Cardew, Stockhausen Serves Imperialism, and Other Articles. With Commentary and Notes, London (Latimer New Dimensions) 1974. 
I didn't pay much attention.

Right. Because it wasn't based in...

...in affirmative action...

Uhu. How do you reconcile your utopian '50s and '60s views with...

With the present time? I don't try to reconcile it with American politics, if that's what you're saying. I've been all along, very clearly against American government. I'm a Thoreauvian ${ }^{16}$ anarchist: I don't vote... I look forward to the time when no-one else does, either.

But do you not think that there may be certain directions that you could actually use your vote that would eventually generate that? No?

No, no, I don't.

Do you think that's something based in American politics, or do you think there are possibilities elsewhere?

16 Henry David Thoreau (1817-1862), amerikanischer Philosoph des Transzendentalismus. Zum Verhältnis von Cage und Thoreau siehe Christopher Shultis, Silencing the Sounded Self. John Cage and the American Experimental Tradition, Boston (Northeastern University Press) 1998. Für weitere allgemeine Informationen bzw. Thoreaus Bücher online sieh beispielsweise:

http://www.transcendentalists.com/1thorea.html oder unter http://eserver.org/thoreau/ 
Government in general... I think we have more serious problems that government is not able to solve.

You mean ecological, and so on...

All those things. We're almost ruining the whole globe in our interest in government. We have, I think it is, 158 separate governments in a place where there should be only the solution of problems, otherwise we're all going to, em, skip the... whatever it is...

Yeah, so would you be for some kind of world council in that sense?

Not involving politicians, but involving intelligent people.

How would the selection be made, or are you not talking about a selection?

I'm talking about the problems, and solving the problems. And we generally solve problems by getting people who know something about the materials involved. Governments are concerned with power, and money, and neither one of those things is important. The important thing is to keep the thing working. And the solutions to that have been put forward, as I've pointed out in my books, by McLuhan and Fuller ${ }^{17}$, and there may be better, or improved versions of those now. Fuller never gave a fixed idea, he gave an indeterminate idea, that could change as the possibilities changed. I have no

17 Marshall McLuhan (1911-1980), kanadischer Kommunikationswissenschaftler; weitere Informationen unter:

http://www.mcluhan.utoronto.ca/mm.html oder http://hoshi.cic.sfu.ca/ guay/Paradigm/McLuhan.html;

Richard Buckminster Fuller (1895-1983), amerikanischer Erfinder, Architekt, Philosoph, Ingenieur, Mathematiker, Poet, Kosmologe; weitere Informationen unter: http://www.bfi.org/introduction_to_bmf.htm. 
confidence in government, of any country. I repeat, then, the life of Emma Goldman, and the book... it's at the root of my basis... the basis of my text called Anarchy, which is just now published in the Bucknell Review ${ }^{18} \ldots$

But would you say that in terms of centres of power or that kind of analysis, do you not think that a dissolution, a disintegration, and an increased number of devolving centres of power on increasingly more specific geographical bases would actually be a step towards the kind of thing that you've always talked about? Instead of America, well... instead of Washington and Moscow.

Have what?

Well, for instance, within British politics, I'd propose that Wales, Scotland and Northern Ireland become disengaged from Westminster, and so on.

No, it won't do any good.

You don't think so? How come?

No. The first step will probably be, as it is being, a joining together of differences. Like the joining together of East and West Berlin now. It was in the nineteenth century that all the principalities of Germany formed a nation, and the same thing happened in Italy. We're moving toward a European coming-together, and then what we need is a world coming-together, but not a splitting-apart.

18 Richard Fleming, William Duckworth (Hrsg.), John Cage at Seventy-Five, Lewisburg (Bucknell University Press) 1989, S. 121-208; oder: John Cage, ANARCHY, Middletown, Conn. (Wesleyan University Press) 2001. 
Well, speaking within the Scottish nationalist viewpoint, the notion is a holistic fragmentation, basically; independence from England, but within Europe.

I know, the whole thing is so complicated that it doesn't look as though we're going to have the sense to find a solution. But if each person, if each country by separating from one another, they also separated from government... but they won't do that. If they would, then I would be all for it. I've already done that as an individual.

Uhu, but surely, the greater number of centres of power, the less megalomaniac each centre, and the greater the possibility of moving towards that?

Well, Fuller says the opposite of that, and I think I concur with him.

So in a sense you have a centralist viewpoint.

I have a technological point of view, and we need it, because we have now nearly four times as many people as ever lived on the planet in all of history living on it, at one moment, rather than in thousands of years, and we need to feed those people, and to give them water to drink... and they don't have good water now. Water and air are two of the serious problems. And we don't even pay any attention to them, and as long as we divide the people up continually, it won't solve that. Fuller's plan is to bring it all together, and to bring some intelligence to the solution of water for everyone.

Yeah, but the problem, it seems to me, is not resources - I mean we have plenty of resources - it's just the distribution that's the problem in this sense. Do you think? 
No, I don't think. There are lots of problems.

Hmm... Moving into more personal ecology: the experience of mycology - of looking for a mushroom and not finding it, but finding other species... how's that actually developed in relation to your awareness of the prevalence of indeterminacy? Has it been an influence in that sense?

It's like the United States government - it's a balancing operation to keep things reasonable, because if you use indeterminacy in connection with the gathering and eating of mushrooms, you might kill yourself. Um... the question in mushroom hunting, if you're also going to be eating the mushrooms, is a question of em... of em... success or failure, whereas the music's not involved with that.

You're talking about the success or failure on a biological basis within mycology... but the actual experience of finding or not finding what you're looking for...

Well, that you're almost always involved with, of having no control - the hunter has no control over what he's hunting. When I first came in touch with mushrooms, I was looking for strawberries. Ha ha.

Ha ha.

But there weren't any strawberries - wild strawberries; there were mushrooms, though.

So is that how you got into mycology? 
No, that's a longer story... I became interested in wild foods largely because I was poor. And last night, a young man came up to me and said that he wanted me to look at his music, so I looked at it and I said it didn't interest me. And, uh, after we talked briefly, he explained that he wanted to make a living, and I said you have to decide whether you want to make a living or whether you want to make music. And he said he really wants to make music, and I then said he could eat wild food, which was free, and he wouldn't have to worry about money. And that's the attitude I actually took, in my life.

Did you find that actually a practical attitude at that point?

Oh yes, and at that point, I read about an English lady who managed to walk around the entire world without any money, just eating wild food, and she sustained herself. It's quite possible.

But surely, within the macrobiotic diet as subscribed to by yourself, you have to be involved with...

It's rather elegant when it's urban. Ha ha ha!

...yeah, you have to get it coming in. Ha ha. You can't pick it yourself!

Right. It's like an art.

Precisely... another version of the macrobiotic diet being, of course, that you can only eat what you find in your immediate area... I remember you once wrote about the timbral aspects of the prepared piano in almost macrobiotic 
terms, or at least in terms of Duchamp's ${ }^{19}$ found objects; I mean, do you find that the parameter of timbre aids music implicitly in the sense of, for instance, generating a further indeterminacy, or the possibility of further...

Yes, and particularly in the percussion section of the orchestra, if we're talking purely about music, because it's involved with all the things that haven't been organised like the violins and the brass and the woodwinds have. The percussion is dealing with, uh, noises... and one drum is quite different from another drum, and instead of wanting the best drum, you have to take the drum which you have.

Mhm. Mhm. It seems to me that in that sense, em, kind of extending that, that there's a very practical aspect to your attitude in general.

Right. I think that the determinist position is very much related to a lot of occidental thinking which moves toward a goal which is non-existent; one goes toward a centre, toward an idea. In the Zen point of view, every sound is at the centre so you have a multiplicity of centres. That's all that Zen is; there's nothing peculiar about it.

Yeah. I know you're very influenced by oriental philosophy, but I've also heard you mention your interest in Wittgenstein, for instance... How do you stand in general to occidental philosophy?

Well I like Wittgenstein mainly because of the language, which I think is very beautiful. And his strong relation to Buddhism... ${ }^{20}$ which isn't expressed, but

19 Marcel Duchamp (1887-1968), amerikanischer Künstler franz. Abstammung. Zum Verhältnis von Duchamp und Cage siehe William und Moira Roth, John Cage on Marcel Duchamp: An Interview, in: Art in America, 61/1973, Nr. 6 (Nov.-Dez.), S. 72-79; erneut abgedruckt in: Moira Roth, Difference/indifference: Musings on Postmodernism, Marcel Duchamp and John Cage, Amsterdam (G and B Arts International) 1998, S. 71-83. 
which... I mean isn't expressed in those words... One can become empty and I think that a lot of Wittgenstein, for instance, moves in that direction. He asks such questions that the mind is back to zero, as in...

Is that surely not more a spiritual viewpoint than a practical viewpoint?

Well, if you think so, yes. Ha ha ha.

Ha ha ha. Fair enough. Have you come into contact with the work of Roland Barthes, Jacques Derrida, Jean François Lyotard, all these people? ${ }^{21}$

I'm not a great student of it, but I know there's a connection.

Do you find a connection between, for instance, a text like Barthes' The Death of The Author ${ }^{22}$ and your own work?

I think there is, but I'm not a student of it.

Right. For instance, within Critical Theory do you find the Text / Work differentiation a useful approach?

20 Siehe beispielsweise Ludwig Wittgenstein, Lectures on Religious Beliefs, in: Lectures and Conversations on Aesthetics, Psychology and Religious Belief, zusammengestellt und notiert von Yorick Smythies, Rush Rhees und James Taylor; hrsg. von Cyril Barrett, Oxford (Basil Blackwell) 1966, S. 53-72.

$21 \mathrm{Zu}$ den hier angesprochen Vertretern der Postmoderne siehe beispielsweise Rolf Günter Renner, Die postmoderne Konstellation : Theorie, Text und Kunst im Ausgang der Moderne, Freiburg, Breisgau (Rombach) 1988.

22 Roland Barthes, Der Tod des Autors (1967/68), in: Fotis Jannidis et al. (Hrsg.), Texte zur Theorie der Autorschaft, Stuttgart (Reclam) 2000, S. 185-193. 
I don't follow you; what kind of difference?

Well, the idea being that, for instance, with a Beethoven quartet, on the one hand you have a Work and on the other hand you have...

The performance?

...kind of the connection between the Work and what happens; the Work and... the area defined as Text... in between the Work and the experience, basically...

I think that my view is that things that are different are different.

Ah; ha ha ha!

And that things that seem to be connected aren't necessarily connected. For instance, I say composing is one thing, listening is another and, em, performing is the third... and what can they possibly have to do with one another? Because they're very different activities.

Mhu. Did you ever actually feel like dispensing with the notion of composer?

Uh, well, it's a little late for me... ha ha. I don't have to worry: I'll be dispensed with before that! Ha ha ha. I wouldn't want to dispense with it, because in the dictionary it says that I'm a composer; and it doesn't say anything else - it says "American composer". Mhm? I don't see anything wrong with the word "composer"... in a sense it means "putting things together", and I put them together in such a way that they're not fixed in a fixed way but flexibly work together. 
Yeah, but implicitly built into the notion of a score is dictation.

Uh, only if it's a fixed relation of the parts, but if there are several parts and there's no fixed relationship, then there's nothing built-in. No fixed relation built in.

But it can still be an influence.

Of course, but it's only because it's practical, that it doesn't in any way determine the, eh, what happens.

On the other hand, is improvisation possible?

Improvisation is quite another thing and is something that I want to avoid. Most people who improvise slip back into their likes and dislikes, and their memory, and they don't make any... they don't arrive at any revelation that they're unaware of.

So does this mean that your own notion of the function of the composer is associated with the notion of Buddhist teaching, in a sense? In that there is an irrelevance involved in the activity which is just simply a matter of engaging in an activity which requires discipline?

Well, I'm not exactly sure that I see eye-to-eye with what you're saying, but it's in that direction. It's since 1952, which is nearly forty years ago, I don't write any fixed relation of parts. Ha ha ha. No, I do everything very precisely, and what I'm interested in is having each thing be uniquely itself, and not in terms of improvisation. If I write an improvisation, as one of them was performed here, I, uh, I write specific limitations for the improvisation so that it leads the musician into a situation with which he's unfamiliar. 
Do you find a correspondence between the notion of the score and that of koan $^{23}$ ?

A score, you see, is a fixed relation of parts, so I don't see any relation between that and koan.

On the other hand, you've written scores which have been non-fixed relationships of parts.

No, it's a misuse of the word "score". A score is a fixed relation of parts. We say "score" and "parts", distinguishing the fixed relation with the unfixed. The koan presents a problem which can't be solved, but what I'm doing is giving something that can be done, hm?

It can be done, yeah, but that's not the same as a solution, surely.

Why not? Because what it's about is giving directions for the making of music. The koan is involved not with the making of music but the, em, coming to enlightenment, and it's working with mental processes, and I'm not dealing with that...

You would say you're not dealing with epistemological issues?

I'm dealing with sounds.

Sure.

${ }^{23}$ Konzept des Zen Buddhismus: Koan ist ein Problem, das sich einer logischen Lösung nicht erschließt. 
It's the difference between going out to the world of relativity, and going... the koan goes into the absolute. It's involved in Buddhism with enlightenment, and all I've been doing is, uh, working with music.

Sure. So what would you say the function of the score per se is?

I think it's a way of writing to strangers, people whom you don't know, giving them the directions for how to do something when you won't be present. Hm?

So in that sense, you're kind of interested in the notion of presence?

No, I know that I'm going to die, and I won't be here, and I'm writing these letters to people I don't know. Ha ha. Who may be interested in doing what I suggest... They're almost bound to be...

Why do you say, "they're almost bound to be"?

Well, because I've become so notorious.

Ah, so it speaks of history, rather than your intention per se.

It's almost certain that someone will be interested. I was interested... and it looks as though others will be. 